Филип Крчмар

Универзитет у Новом Саду

докторанд

kikazr@gmail.com
Оригинални научни рад

примљено: 26. мај 2011

прихваћено: 1. октобар 2011

\title{
ЈОХАН ХАЈНРИХ ШВИКЕР \\ И ЊЕГОВ ДРУШТВЕНИ АНГАНЖМАН У ВЕЛИКОМ БЕЧКЕРЕКУ
}

Сажетак: ${ }^{1}$ Уз кратак осврт на биографију и допринос Јохана Хајнриха Швикера српској историографији, у раду се на основу натписа великобечкеречког листа GrossBecskereker Wochenblatt разматра његово деловање у друштвеном животу овог града.

Кључне речи: Јохан Хајнрих Швикер, Велики Бечкерек, Банат, Торонталска жупанија, историографија, педагогија, Gross-Becskereker Wochenblatt.

Име Јохана Хајнриха Непомука Швикера (1839-1902) добро је познато у српској историјској науци: његова Политичка историја Срба у Угарској, која обухвата период од Велике сеобе (1690) до укидања Илирске дворске канцеларије (1792), више је, него иједно друго дело о прошлости Срба у Хабзбуршкој монархији и Угарској, било коришћено у српској историографији. ${ }^{2}$ Швикер припада плејади учених банатских Шваба који су у другој половини XIX, а и касније, у првој половини XX века, активно радећи на документовању прошлости своје етничке групе, узгредно обрађивали и теме из српске историје и културе. ${ }^{3}$ Швикер је на том

\footnotetext{
${ }^{1}$ Поводом 150 година од Историје Тамишког Баната

${ }^{2}$ На основу овог рада Швикер је изабран и за дописног члана Српске академије наука у Београду; в. Славко Гавриловић, Реч о J. Х. Швикеру и Политичкој историји Срба у Угарској, у: Јохан Хајнрих Швикер, Политичка историја Срба у Угарској (превод Томислав Бекић, приређивач С. Гавриловић), Нови Сад 1995, 7; Alexander Krischan, Bio-Bibliographische Skizzen. Deutsche Beiträge zur Banater Historiographie, Freiburg 1983, 66.

${ }^{3}$ Њихови радови појављивали су се у виду чланака или фељтона у немачкој штампи, посебних мањих монографија или кратких извода из архивске грађе у оквиру научне периодике: Leonhard Böhm, Eine Serbenerhebung wider die Türkenherrschaft im Jahre 1594 im Banat, Südungarische General-Anzeiger, 15.12.1907; Исти, Historische Bilder aus dem Banat, Temeschwar 1915, 45-54; Феликс Милекер, Прошлост српско-православног владичанства вршачког, Нови Сад 1891; Felix Milleker, Zwei serbische Nationalgesänge aus dem XV Jahrhundert aus der Wrschatzer Gegend, Wrschatz 1938; Felix Milleker, Kurze
} 
пољу отишао корак даље, будући да су по свом обиму и квалитету његови радови о прошлости Срба далеко превазишли слична дела осталих немачких завичајних историчара из Баната. Осим већ поменуте Политичке историје Срба у Угарској, они обухватају још и Историју ирквене уније у хрватској Војној крајини и иједињење Београдске и Карловачке митрополије 1731. године. ${ }^{5}$ Поред тога, познато је да је Швикер планирао да напише историју српских црквених сабора у XVIII веку, као и Историју цркве и школства код Срба (које није написао услед недостатка материјалних средстава). ${ }^{6}$ Такође, он је 1878 . год. превео на немачки двотомну историју Срба Бењамина Калаја. ${ }^{7}$ Од осталих значајнијих Швикерових историјских дела ваља споменути следећа: Историја Тамишког Баната ${ }^{8}$ (објављена у Великом Бечкереку пре тачно 150 година), Последње године владе Марије Терезије 1763$1780,{ }^{9}$ Статистика Угарског краљевства, ${ }^{10}$ Немии у Угарској и Ердељу, ${ }^{11}$ Историја аустријске војне границе,${ }^{12}$ Цигани у Угарској и Ердељу, ${ }^{13}$ Угарско краљевство. ${ }^{14}$

Политичка историја Срба у Угарској намеће се као најзначајнији Швикеров допринос српској историјској науци. ${ }^{15}$ Шест година он је марљиво радио на прикупљању грађе из бечких и будимпештанских архива, а осим тога се послужио и радовима оновремених мађарских и немачких историчара. ${ }^{16}$ Прва два

Geschichte der Serben im Banat, Vršac 1941 (необјављен рад); Исти, Das Banat und serbische Kultur, Wrschatz 1938; Leo Hoffmann, Popis srpskog pravoslavnog sveštenstva u Banatu iz 1754, Glasnik Istorijskog društva u Novom Sadu 2 (1929), 411-412; Исти, Die Wohlhabenheit des griechisch-orthodoxen Klerus in der Wojwodina im 18. Jhdt., Sondernabdruck aus GID, Neusatz 1929; Исти, Spisak članova srpske i grčke trgovačke kompanije u Temišvaru iz 1753, Glasnik Istorijskog društva u Novom Sadu 9 (1936), 427-429; Исти, Kikindski distrikt 1755, Glasnik Istorijskog društva u Novom Sadu 10 (1937), 323-332; Eugen Klier, Jovan Sterija Popović, 1806-1856, Wrschatz 1934; Исти, Paja Jovanović achtzigster Geburtstag. Reportbiographie, Wrschatz 1938.

${ }^{4}$ Johan Heinrich Schwicker, Zur Geschichte der kirchlichen Union in der croatischen Militärgrenze, o. O. 1874; овај рад штампан је 1875. год. у 52. свесци часописа Archiv für österreichische Geschichte. На српски језик био је превођен у два наврата: први пут 1991, други пут 1995. године и у оба наврата преводилац је био Никола Живковић: Хисторија унијаћења Срба у Жумберку, Крагујевац 1991; Историја унијаћења Срба у Војној крајини, Нови Сад 1995.

${ }^{5}$ Johan Heinrich Schwicker, Die Vereinigung der serbischen Metropolien von Belgrad und Carlowitz im Jahre 1731, Wien 1881; овај рад, непреведен, налази се у Библиотеци Матице српске у Новом Саду (читаоница раритета).

${ }^{6}$ Ова намера је видљива из предговора његове Политичке историје Срба у Угарској; Јохан Хајнрих Швикер, Политичка историја Срба у Угарској (превод Томислав Бекић), Нови Сад 1995, 12.

${ }^{7}$ Kállay Benjámin, Geschichte der Serben, Budapest 1878.

${ }^{8}$ Johan Heinrich Schwicker, Geschichte des Temeser Banats, Groß-Betschkerek 1861.

${ }^{9}$ Johan Heinrich Schwicker, Die letzten Regierungsjahre der Kaiserin-Königin Maria Theresia 1763-1780, Wien 1871-1872.

${ }^{10}$ Johann Heinrich Schwicker, Statistik des Königreichs Ungarn, Stuttgart 1877.

${ }^{11}$ Johann Heinrich Schwicker, Die Deutschen in Ungarn und Siebenbürgen, Wien-Teschen 1881.

${ }^{12}$ Johann Heinrich Schwicker, Geschichte der österreichischen Militärgrenze, Wien-Teschen 1883.

${ }^{13}$ Johann Heinrich Schwicker, Die Zigeuner in Ungarn und Siebenbürgen, Teschen 1882.

${ }^{14}$ Johan Heinrich Schwicker, Das Königreich Ungarn, Wien 1886.

${ }^{15}$ Српски превод овог дела појавио се 1995. године у Новом Саду; приређивач текста био је Славко Гавриловић, а преводилац Томислав Бекић.

${ }^{16}$ С. Гавриловић, нав. дело, 8. 
поглавља објавио је 1879. године у будимпештанском часопису Књижевни извештаји из Угарске [Literarische Berichte aus Ungarn]. ${ }^{17}$

Швикер не само да је био део српске историографије, већ и део српске историје. О томе сведочи рад М. Томандла, који је својевремено за Гласник Историјског друштва у Новом Саду приредио и научној јавности предочио сачувану преписку Швикера и горњокарловачког епископа Теофана Живковића. ${ }^{18}$ Темељно анализирајући ову кореспонденцију, Томандл је приказао Швикерове везе са српским свештенством и његове ставове о важним црквеним и политичким питањима седамдесетих и осамдесетих година 19. века. На крају је закључио да Швикер „није био пријатељ српског народа, нити поборник за 'српску ствар' како се представљао, већ је покушавао да од српског свештенства извуче за своје радове што више користи““19 (његова објективност у приказу српско-мађарских односа доведена је у питање, будући да је примећено да је редовно стајао на позицији великомађарских идеја и ставова; с друге стране, његово поимање односа бечког двора према Србима нешто је непристрасније и уравнотеженије). ${ }^{20}$ Из Томандловог рада види се да је о Швикеру писала и новосадска Застава, а о његовим везама са српским свештенством сведочи и занимљив податак да је Политичка историја Срба y Угарској била посвећена, „у дубокој верности и поштовању“, српском патријарху Прокопију Ивачковићу. ${ }^{21}$

Потомак немачких колониста из Трира, Швикер се родио у банатском месту Ново Бешеново (рум. Dudeştii Noi, нем. Neubeschenowa), недалеко од Темишвара. ${ }^{22}$

\footnotetext{
17 Johan Heinrich Schwicker, Die Serben in Ungarn. Historisch-politische Studie, Literarische Berichte aus Ungarn 3, Budapest 1879, 49-84, 342-381.

${ }^{18}$ Миховил Томандл, Преписка између J. Х. Швикера и епископа Теофана Живковића, ГИД VIII, Нови Сад 1935, 422-438; ГИД ІХ, Нови Сад 1936, 65-78.

19 У закључку свог рада Томандл је записао: „Просуђујући дубље ову преписку ми морамо да константујемо, да Швикер није био пријатељ српскога народа каквим су га у оно доба сматрали и каквим га је приказивала Застава, кад је 1879. писала о њему, 'да је поборник за српску ствар', када се из ове преписке види да је радио само за свој лични интерес. Све што је чинио, он је то радио из материјалних побуда, имајући пред собом само један циљ, наиме: да од српске патријаршије, од српског епископата, а и од српског народа извуче за своје историске радове што више користи. Нека особита љубав и неко велико одушевљење за српски народ није владало у њему. Најмање у доба Милетићеве ере и снажне мађаризације. Немац Швикер, издавајући се за пријатеља српског народа, могао је донекле да стече симпатија код Срба већ из разлога, што беше родом из Тамишког Баната (у Новој Бешенови), што је учитељевао у Чакову и Великом Бечкереку, дружио се са Србима у Пешти и писао историске студије о српско-црквеним стварима, али он у души својој беше Великомађар у сваком погледу, и он је као такав делао и војевао за великомађарску државну идеологију...“; М. Томандл, Преписка између J. Х. Швикера и епископа Теофана Живковића, ГИД ІХ, Нови Сад 1936, 78.

${ }^{20}$ С. Гавриловић, нав. дело, 9.

21 Посвета гласи: „Његовој Екселенцији високоцењеном господину Прокопију Ивачковићу, грчкоисточном архиепископу карловачке архидијецезе, српском митрополиту и патријарху, истинском тајном саветнику његовог ц. к. Апостолског Величанства, витезу првог степена ц. к. реда Гвоздене круне, почасном доктору теологије ц. к. универзитета у Черновицу. Посвећено у дубокој верности и поштовању“. Johan Heinrich Schwicker, Politische Geschichte der Serben in Ungarn. Nach archivalischen Quellen dargestellt, Budapest 1880.

${ }^{22}$ О Швикеру в.: А. Krischan, нав. дело, 62-74; С. Гавриловић, нав. дело, 7-9; Anton Peter Petri, Biographisches Lexikon des Banater Deutschtums, Marquartstein 1992, 1798-1799.
} 
Рано оставши сироче, најпре је похађао Учитељски завод у Вршцу (1854-1856), и затим је конкурисао за место учитеља у Новом Саду. На наговор темишварског каноника Александра Бонаца, одатле се пребацио у католичку школу у Чакову, где се није дуго задржао - свега годину дана. Од 1857. до 1869. боравио је у Великом Бечкереку, где је похађао пијаристичку гимназију, положио матуру, заинтересовао се за историју, дошао у ближи додир са мађарским језиком и радио као учитељ и педагог. Ту је објавио и свој први озбиљнији рад из области историје - Историју тамишког Баната. ${ }^{23}$ На позив тадашњег министра културе Јожефа Етвеша, прешао je 1869. године у Будим, где је постављен за директора Централног учитељског завода. Овде је обављао разне просветне функције и добио докторско звање филозофског факултета 1878. године. Бавио се активно и политиком, заступајући интересе ердељских Саса у Царевинском већу Аустроугарске. Био је почасни члан Историјског друштва у Берлину и дописни члан тамошњег Антрополошког друштва. Цар Фрања Јосиф одликовао га је Златном медаљом за уметност и науку. Умро је 1902. године. ${ }^{24}$

Након кратког боравка у Чакову, где је радио као суплент, осамнаестогодишњи Швикер се 1857. године на наговор Александра фон Бонаца ${ }^{25}$ преселио у Велики Бечкерек, да похађа тамошњу пијаристичку гимназију. Овде је провео наредних дванаест година, засновао породицу ${ }^{26}$ и активно се укључио у друштвени живот града. Запосливши се као наставник у гимназији, бавио се историјом, педагошким и просветним радом, те економским и другим питањима од јавног значаја. Стекао је 1865. године звање професора немачког језика и књижевности, географије и историје. Спријатељио се са чувеним сликаром Константином Данилом, који је у то време живео у Бечкереку и израдио портрете Швикера и његове породице. ${ }^{27}$

Најбогатији, а за сада изгледа и једини извор података о Швикеровом боравку и интензивном друштвеном ангажману у Великом Бечкереку представља

\footnotetext{
${ }^{23}$ Johann Heinrich Schwicker, Geschichte des Temeser Banats. Historische Bilder und Skizzen, Großbetschkerek 1861.

${ }^{24}$ А. Р. Petri, нав. дело, 1798-1799.

${ }^{25}$ Александар Бонац једна је од најзначајнијих личности Католичке цркве у историји Баната; рођен је 1812. године у Маронжију у Француској. Школовао се у Араду, Темишвару, Сегедину и Бечу; студирао је филозофију и теологију; за свештеника је заређен 1837. године у Темишвару, а свештеничку дужност обављао је у Карансепешу и Трибсветеру (данашњи Томнатик у Румунији). Обављао је важне црквенопросветне функције широм Баната (виценотар и секретар чанадског бискупског двора, професор теологије у Темишвару, школски инспектор за немачке и мађарске школе у Војводству Србији и Тамишком Банату итд.). Седам година (1853-1860) био је викар Чанадске бискупије, да би 1860. био постављен за бискупа од стране цара Фрање Јосифа лично; од 1862. године био је папски помоћник Пија IX; одликован је Витешким крстом Реда круне првог степена; учествовао је 1869. године на 70. Ватиканском концилу. За живота је саградио и реновирао преко 40 католичких цркава у Банату, а његове задужбине и разни прилози намењени у те сврхе премашили су вредношћу суму од два милиона форинти. Умро је 1889. године у Темишвару, где је и сахрањен (А. P. Petri, нав. дело, 183-185).

${ }^{26}$ Швикер се у В. Бечкереку оженио и добио два сина: Бруна (1860) и Алфреда (1864). Обојица су похађала бечкеречку гимназију и касније остварила успешне академске каријере: Бруно као географ и историчар, а Алфред као хемичар. О томе в.: А. Р. Petri, нав. дело, 1797.

${ }^{27}$ Ови портрети данас се чувају у Народном музеју Зрењанин (Ф. К.).
} 
локални недељник на немачком језику Gross-Becskereker Wochenblatt $^{28}$. У годиштима овог листа од 1857. до 1869. године сачувано је тридесетак натписа - од кратких огласа до опширних елабората - који су потписани Швикеровим именом и презименом, а на основу којих се може пристојно реконструисати његово деловање на научном, просветно-педагошком, економском и верском плану.

Један од најранијих натписа у Wochenblatt-у у вези са Швикером је његов „историјски првенац“: Гроф Мерси, рад који је излазио у наставцима од 7. априла до 5. маја 1860. године. ${ }^{29}$ У њему је Швикер темељно обрадио живот и војевања Клаудијуса Флоримунда Мерсија, првог намесника Баната после аустријског освајања ове области у рату 1716-1718. У првој и најстаријој Мерсијевој биографији, ${ }^{30}$ Швикер је ставио посебан акценат на његово управљање Банатом и мере које су допринеле привредном уздизању ове провинције. Врло занимљив је и приказ мање познатих Мерсијевих доживљаја у Италији током Рата за шпанско наслеђе (1701-1714) и рата 1717-1720.

Неколико година касније, поводом обележавања три века од рођења Вилијема Шекспира, Швикер је у два броја Wochenblatt-а објавио рад посвећен овом славном енглеском писцу. ${ }^{31}$ У првом делу је прилично детаљно описао његов живот, док је у наставку дао анализу његовог стваралачког опуса у најопштијим цртама.

У издању великобечкеречког књижара Франца Бетелхајма 1861. године појавила се Швикерова Историја Тамишког Баната. ${ }^{32}$ Велики Бечкерек је тако постао родно место банатске Heimatgeschichte, ${ }^{33}$ будући да је реч о једном од првих радова завичајне историографије на овом подручју (Швикер је у то време имао свега 22 године!). ${ }^{34}$ Wochenblatt је објавио рекламу са прегледом садржаја, а цена књиге износила је три форинте аустријске вредности. ${ }^{35}$

\footnotetext{
${ }^{28}$ Први број Gross-Becskereker Wochenblatt-a појавио се 4. јануара 1851. године и ово је најстарији немачки лист на територији данашње Војводине. Лист је покренуо регенсбуршки књижар Франц Паул Плајц, који је 1847. године добио штампарску привилегију. О томе в.: Ferenc Nemet, Istorija štampe u Velikom Bečkereku 1849-1918, Zrenjanin 2007; Branko Bešlin, Vesnik tragedije. Nemačka štampa u Vojvodini 1933-1941, Novi Sad 1995; до појаве мађарског недељника Torontál 1872. године, Wochenblatt је био једини новински лист у Вел. Бечкереку.

${ }^{29}$ Johann Heinrich Schwicker, Graf Mercy, Gross-Becskereker Wochenblatt (=GWb) 14, 7.4.1860, 6-7; GWb 15, 14.4.1860, 5-6; GWb 16, 21.4.1860, 6-7; GWb 17, 28.4.1860, 5; GWb 18, 5.5.1860, 10.

${ }^{30}$ О Мерсију в. такође: Josef Wolf, Kaiserlicher Soldat und Statthalter. Claudius Florimund Graf von Mercy und sein Wirken im Banat, Banater Kalender 2008, Erding 2009; Gerhard Seewann, Zur Familiengeschichte der Grafen Mercy und Mercy-Argenteau, Südostdeutsches Archiv, XIX/XX, München 1977, 53-69; Josef Kallbrunner, Ein Lothringer als Träger deutscher Kultur im Banat. Vorschau auf ein Bild des Grafen Claudius Florimund Mercy, Heidelberg 1952; Adam Maurus, Claudius Florimund Graf von Mercy, Volkswart 8, Novi Sad (Juli-September) 1934; Franz Wettel, Biographische Skizzen. Beiträge zur Geschichte des Temeser Banats, Temeswar 1932; Ludwig Baróti-Grünn, Adatok Mercy Klaudiusz Florimund gróf élétehez, Történelmi és Régészeti Értesitö 8, Temeswar 1910;

${ }^{31}$ Johann Heinrich Schwicker, William Shakespeare. Erinnerung an dessen dreihundertjährigem Geburtsfeste (23. April 1864), GWb 18, 30.4.1864, 3-5; GWb 19, 7.5.1864, 3-4.

${ }^{32}$ Johan Heinrich Schwicker, Geschichte des Temeser Banats, Gross-Becskerek 1861.

${ }^{33}$ Heimatgeschichte (нем.) - завичајна историографија.

${ }^{34}$ Исте године се у Белој Цркви појавио истоимени рад Леонарда Бема: Leonhard Böhm, Geschichte des Temeser Banats, Weisskirchen 1861; О Бему в.: Živan Ištvanić, Leonard Bem (1833-1924). Biografija i
} 
Овај рад наишао је на одличан пријем у научним круговима, и то не само у Банату већ и шире: бечки Католички књижевни лист [Katolische Literatur-Zeitung] објавио је приказ Историје Тамишког Баната, у ком је ова књига топло препоручена читалачкој публици, а истовремено је изражена нада да ће Швикер наставити да се оглашава резултатима својих историјских истраживања ${ }^{36}$. Wochenblatt je 1865. године пренео и рецензију из једног темишварског листа ${ }^{37}$, у којој је нарочито истакнута ауторова објективност ${ }^{38}$. Ову критику потписао је извесни „проф. Часар“ („Prof. Császár“), који је своју похвалу завршио речима:

Истинско је задовољство проживљавати историју Баната са овом књигом у руци. Пошто желимо да сви образовани становници Баната буду у могућности да себи приуште ово задовољство, примећујемо, да је оно доступно по цени од две уместо три форинте аустријске вредности. ${ }^{39}$

Захваљујући неколицини очуваних огласа у Wochenblatt-у данас је познато да је Швикер био члан Великобечкеречког паробродарског удружења [Gr.Becskereker Dampfschifffahrts-Gesellschaft]. У два таква огласа он се спомиње као „актуар“, односно статистичар, ${ }^{40}$ а у једном као записничар седнице ове корпорације одржане 14. фебруара 1869 . године. ${ }^{41}$

Швикер се ангажовао и као секретар Великобечкеречког трговачког збора [Gross-Becskereker Kaufmannshalle]. У том својству се у јесен 1867. обратио јавности Великог Бечкерека и Торонталске жупаније поводом акције овог удружења везане за решавање питања железница ${ }^{42}$. Наиме, предвиђени нацрт железничке мреже за Угарску, који је те године објавило Високо краљевско угарско Министарство за јавне радове и комуникације, претио је да угрози економске интересе Великог

bibliografija, Bela Crkva u Banatu 2010; Felix Milleker, Leonhard Böhm (1833-1924). Monograph des Banats: Sein Leben und seine Werke, Wrschatz 1925.

${ }^{35}$ Im Verlage von Fr. P. Bettelheim in Gr.-Becskerek, GWb 26, 29.6.1861, 3; GWb 28, 13.7.1861,2; књига је подељена у три веће целине и обухвата дванаест различитих временских епоха: I одељак: Банат од најстаријих времена до турског подјармљивања. Прво доба: Време почињуће сеобе народа. Друго доба: Време зачетка државног поретка и борбе против спољних непријатеља. Треће доба: Учвршћивање државног поретка и зачеци турске опасности. Четврто доба: Храбри борци против Турака. Пето доба: Опасност од Турака. Шесто доба: Жалосно време по Банат. II одељак: Банат као турски санџак. Седмо доба: Турска владавина. Осмо доба: Банат и Ердељ. Девето доба: Турска звезда на заласку. Десето доба: Ослободилачки рат - срећно време за Банат. ІІІ одељак: Банат под кућом Аустрије. Једанаесто доба: Нова изградња провинције. Дванаесто доба: Банат под коморском управом до поновног утеловљења у Угарску. Додатак: Етнографско-историјско-статистички подаци о народима који насељавају Банат од његовог поновног освајања.

${ }^{36}$ Literarisches, GWb 31, 2.8.1862, 5-6.

${ }^{37}$ Temesvarer Wochenblatt 13, 12.11.1864.

38 „Macht sich aber ein Forscher ohne alle Tendenz, blos aus Wahrheitsliebe an dies Werk; vollendet er seine Aufgabe mit jener historischen Unpartheilichkeit, die selbst den erbittersten Gegner nicht erregen darf: so verdient er allerseits die größte Anerkennung. Der Verfasser des vorliegenden Werkes darf jedenfalls zu solchen unpartheiischen Geschichtsforschern gezählt werden“. Literarisches, GWb 2, 14.1.1865, 6.

${ }^{39}$ Literarisches, GWb 2, 14.1.1865, 6.

${ }^{40}$ Anzeige, GWb 4, 23.1.1869, 5; Anzeige, GWb 5, 30.1.1869, 6; GWb 6, 6.2.1869, 6.

${ }^{41}$ Anzeige, GWb 7, 13. 2. 1869, 4.

${ }^{42}$ Die Eisenbahnfrage, GWb 46, 16.11.1867, 7-8. 
Бечкерека; стога је Трговачки збор покренуо иницијативу да се план измени на нивоу Торонталске жупаније; овај се подухват завршио успешно. Швикерово име се и у каснијем периоду појављује у новинским огласима везаним за ово удружење, махом у објавама и позивима на седнице и балове. ${ }^{43}$

Радећи као учитељ у гимназији, Швикер се посветио унапређењу народне просвете и на том пољу је оставио и највише трагова у Великом Бечкереку. Недуго након свог доласка у овај град, он се спомиње као учесник редовне годишње конференције наставника Средњеторонталског дистрикта, одржане 22. августа 1858. године; ово је уједно и најранији новински помен Швикера у Великом Бечкереку. ${ }^{44}$ Осим редовне наставе у гимназији, држао је и приватне часове. ${ }^{45}$ у јесен 1866. огласио се у Wochenblatt-у чланком под називом Pодитељима, у ком је изнео потребу за оснивањем једне реалне школе у граду, која би била намењена школовању деце занатлијског и трговачког сталежа. ${ }^{46}$ Швикер је добро уочавао значај занатства и трговине за Велики Бечкерек, који је у то време већ скоро сто година имао статус трговишта. ${ }^{47}$ Приметио је да град стагнира и заостаје по броју становника за осталим градовима у окружењу (Суботица, Сегедин, Нови Сад, Вршац, Арад), те да се становништво (а првенствено омладина) одлива у друге средине. У циљу заустављања тог тренда, Швикер је сматрао да је неопходно ојачати и изградити докраја грађански сталеж, за шта су биле неопходне занатлије и трговци; подвукао је да је образовање предуслов за остварење тог циља, те да је реалка „насушна потреба нашег занатског сталежа““. ${ }^{48}$

Своју идеју за отварањем реалке Швикер је подробније разрадио у посебном елаборату под називом Предлог за оснивање грађанске школе у Великом Бечкереку, који је у наставцима објављиван средином наредне године. ${ }^{49}$ Уводни део ове студије посветио је значају образовања, народне просвете и школа, те економским потенцијалима Вел. Бечкерека. Говорећи о локалним занатлијама, трговцима и пољопривредницима, као представницима нижег грађанског слоја, истакао је да је за овај сталеж неопходно знање из области које се не може стећи у

\footnotetext{
${ }^{43}$ Ball-Anzeige, GWb 2, 9.1.1869, 9; GWb 3, 16.1.1869, 6; Anzeige, GWb 3, 16.1.1869, 4; GWb 4, 23.1.1869, 4; Annerkennung, GWb 8, 20.2.1869, 5; An das P. T. Publikum, GWb 14, 3.4.1869, 4; Anzeige-Hirdetmény-Обjaвa, GWb 23, 5.6.1869, 4.

${ }^{44}$ Lehrer-Konferenz in Gr.-Becskerek, GWb 37, 10.9.1859, 7-8.

${ }^{45}$ Unterrichts-Anzeige, GWb 29, 22.7.1865, 4; Unterrichts-Anzeige, GWb 29, 21.7.1866 6; Eingesendet, GWb 40, 6.10.1866, 10; Schulunterricht, GWb 34, 24.8.1867, 11; GWb 35, 31.8.1867, 7; GWb 36, 7.9.1867, 8.

${ }^{46}$ Johan Heinrich Schwicker, An die Eltern!, GWb 38, 22.9.1866, 9-10.

${ }^{47}$ Марија Терезија је Привилегијом од 6. јуна 1769. године доделила Вел. Бечкереку статус трговишта. У тој повељи јасно је била назначена намера да се у овом граду даље развијају занати и трговина. О овој проблематици в.: Привилегија Марије Терезије којом уздиже општину Велики Бечкерек на степен тржишта 1769. године у Бечу, Архивска грађа градске Државне архиве у Зрењанину, год. I, св. 1, Зрењанин 1953, 9-16; Рајка Грубић, Занатлије и трговци у прошлости Зрењанина (од XVI до прве половине ХХ века), Рад Музеја Војводине 49, Нови Сад 2007, 211-229.

${ }^{48}$ Johan Heinrich Schwicker, An die Eltern!, GWb 38, 22.9.1866, 9.

49 Johan Heinrich Schwicker, Vorschlag zur Errichtung einer „Bürgerschule“ in Gr.-Becskerek, GWb 21, 25.5.1867, 10-11; GWb 22, 1.6.1867, 11; GWb 23, 8.6.1867, 8-9.
} 
народној школи или гимназији, већ искључиво у једној грађанској школи. Записао je:

Отварање виших и нижих грађанских школа је дакле само захтев датих прилика. Размотримо ли околности и потребе нашег града, лако ћемо увидети да овде имамо бројан сталеж ситних занатлија, али нам у потпуности недостају и тзв. „виши“ практични сталежи [овде је Швикер претходно убројио фабриканте, крупне трговце, архитекте, инжењере, шумаре, рударе, апотекаре и др. - прим. Ф. К.]. Стога нам је хитно потребна нижа грађанска школа, како би се њоме задовољиле духовне тражње сталежа ситних занатлија и трговаца. ${ }^{50}$

У наставку је Швикер детаљно образложио сврху једне такве грађанске школе и „како би се иста могла уредити примерено нашим приликама“. ${ }^{51} \mathrm{У}$ трећем, завршном делу, изложио је своје мишљење о наставном језику, предавачима и ученицима предложене грађанске школе, те „најшкакљивије“ питање - проблем трошкова. Предвидео је да наставни језици у школи буду немачки и мађарски, док српски по Швикеру није био обавезан; ипак, ако би се којим случајем увео, Швикер је предложио најмање три часа недељно. Од наставних предмета, он се определио за исте оне које је раније поменуо у ауторском тексту An die Eltern! (немачки и мађарски језик, географија и историја, аритметика, биологија, физика, нацртна геометрија и краснопис), с тим што је овде уврстио и веронауку. Проценио је да би трошкови градње школе износили близу 3000 форинти, што је за ондашње прилике била прилично велика сума новца, мада је приметио да би се ови трошкови врло брзо исплатили. Елаборат је завршио речима:

Овде сам желео да само једном прописно важну ствар изнесем јавно и подстакнем да се о њој Овде сам желео да само једном прописно важну ствар изнесем јавно и
дискутује. Утешен, сад могу, себи да кажем: Изрекао сам и спасао своју душу!

Овај Швикеров реферат наишао је на веома добар одјек, будући да је Торонталска штедионица (која је почела са радом у новембру исте године) основала фонд за отварање реалне школе у Великом Бечкереку. Прве уплате досегле су суму од 150 форинти, ${ }^{53}$ а директор Штедионице Михаел Менцер позвао је грађанство да приложи новац како би се остварио овај циљ. ${ }^{54}$

Агилност Швикера на пољу народне просвете дошла је још више до изражаја крајем те и почетком следеће године. У Темишвару је децембра 1867. основано Банатско учитељско удружење [Bánsági Tanitóegylet], које je нешто касније променило име у Јужноугарско учитељско удружење [Délmagyarországi

\footnotetext{
50 Johan Heinrich Schwicker, Vorschlag zur Errichtung einer „Bürgerschule“ in Gr.-Becskerek, GWb 21, 25.5.1867, 11

${ }^{51}$ Johan Heinrich Schwicker, Vorschlag zur Errichtung einer „Bürgerschule“ in Gr.-Becskerek, GWb 22, 1.6.1867, 11.

52 "Dixi et salvam animam meam!“; Johan Heinrich Schwicker, Vorschlag zur Errichtung einer „Bürgerschule“ in Gr.-Becskerek III, GWb 23, 8.6.1867, 9; О грађанским школама у В. Бечкереку в.: Александар Станојловић, Петровград, Зрењанин 2004³, 150-153.

${ }^{53}$ Lokales, GWb 47, 23.11.1867, 8.

${ }^{54}$ Aufruf zu Beiträgen für eine Realschule in Gr.-Becskerek, GWb 50, 14.12.1867, 14.
} 
Tanitóegylet]. ${ }^{55}$ Ово тело, чија се делатност простирала на подручју Торонталске, Тамишке и Крашо-северинске жупаније, окупљало је око 400 учитеља и педагога, а циљ му је био да „уједини учитеље ових жупанија без обзира на веру и нацију, да унапреди народно просвећивање и да штити интересе својих чланова““ ${ }^{56}$ Швикер се налазио међу оснивачима овог удружења и пет пута је председавао његовим годишњим скупштинама, ${ }^{57}$ а дао му је огроман допринос и кроз уређивање гласила које је покренуо 1. јануара 1868. у Великом Бечкереку под називом Ungarische Schulbote [Мађарски школски гласник]. Оснивање овог листа, у сарадњи са локалним штампаром Францем Паулом Плајцем и Јожефом Рилом (учитељем из Модоша), било је почетак стручне педагошке штампе у Банату, која је у новинарство укључила велики број истакнутих професора и учитеља. ${ }^{58}$ Швикер је детаљно изложио циљеве листа у предговору првог броја под насловом Шта ми хоћемо. Обим је износио 16-20 страна, а излазио је двапут месечно. ${ }^{59}$ Швикер је наставио да уређуje Ungarische Schulbote и након свог одласка из Великог Бечкерека, с тим што је седиште редакције било пресељено у Будимпешту. Лист је излазио до 1887. године.

Средином 1869. Швикер је ушао у полемику са Вел.-Бечкеречким женским друштвом за доброчинство [Gross-Becskereker Frauenverein] око иницијативе за отварање завода за чување деце предшколског узраста [Kinderbewahranstalt]. ${ }^{60} \mathrm{y}$ опширном чланку под називом An die Frauen!, који је у два дела изашао на странама Wochenblatt-a, он се изјаснио против таквог потеза. ${ }^{61}$ На почетку излагања своје аргументације записао је да такав завод „у својој уобичајеној форми није ништа друго до завод за дресуру, где се деца уче да мирно седе, играју се по команди, рецитују неразумљиве стихове и нажалост се често терају да читају и пишу. Код нас се још увек практикује да дете што је пре могуће почне са похађањем наставе и није нимало сујетно ако дете од 4-5 година познаје слова и пише или чита...“. ${ }^{62}$ У другом делу текста објашњавао је преимућства тзв. „Фребеловог забавишта“, као тада модерног педагошког достигнућа, које је супротставио планираном „заводу“. ${ }^{63}$

\footnotetext{
${ }^{55}$ Ferenc Nemet, Ungarische Schulbote, Náplo 29.3.1995.

${ }^{56}$ Исто.

${ }^{57}$ А. Р. Petri, Нав. дело, 1798.

${ }^{58}$ F. Nemet, Istorija štampe u Velikom Bečkereku 1849-1918, Zrenjanin 2007, 32.

${ }^{59}$ Исто.

${ }^{60}$ Радило се о деци узраста 3-6 година (Ф. К.).

${ }^{61}$ Johann Heinrich Schwicker, An die Frauen! (I), GWb 24, 12.6.1869, 8-9; Johann Heinrich Schwicker, An die Frauen! (II), GWb 25, 19.6.1869, 9-10.

${ }^{62}$ Johann Heinrich Schwicker, An die Frauen! (I), GWb 24, 12.6.1869, 8.

${ }^{63}$ Фридрих Вилхелм Август Фребел (Fröbel) творац је концепта модерног забавишта. Рођен је 21. априла 1782. у Обервајсбаху у Тирингији. По завршетку студија посветио се образовању младих и сарађивао две године у Швајцарској са оцем модерне педагогије Хајнрихом Песталоцијем; отворио је 1816. године Институт за васпитање, по узору на који су настале бројне сличне установе у Швајцарској. Објавио је низ радова у којима је анализирао природу човека и детета. Основао је 1840. године забавиште, у ком је спроводио своје педагошке методе. Оне су биле признате од најистакнутијих педагога тог времена у Швајцарској, Холандији, Белгији, Француској, Енглеској, Шпанији и САД. Умро је 21. јуна 1852 (An die Frauen! (II), GWb 25, 19.6.1869, 9).
} 
Ипак, његово убеђивање изгледа да овог пута није имало учинка, будући да је нешто касније завод ипак основан. ${ }^{64}$ Швикер је у то време (1872) већ напустио Велики Бечкерек.

У огласу Wochenblatt-a из маја 1869, чланови месне римокатоличке црквене општине позвани су на седницу у просторијама градског магистрата; Швикер је потписан као председавајући овог тела. ${ }^{65}$ Главна тачка дневног реда било је усвајање статута црквене општине, о чему сведочи Швикеров говор одржан на отварању поменутог скупа. ${ }^{66}$ Том приликом он је изнео занимљиво схватање положаја католика у Угарској, које је почивало на тези да су католици од дотадашњег повлашћеног положаја и државног старатељства имали само штете, а не користи; таква пракса (туторство државе и обасипање црквених лица почастима, титулама и новцем - прим. Ф. К.) - према Швикеровом мишљењу - довела је до „жалосног раздора између свештенства и верника“. Нацрт поменутог статута требало је да уреди прилике на тај начин да се епископат брине о духовним потребама католика, а црквена општина о „материјалним“ и „организационим“ стварима које немају везе са верским питањима.

Непосредно пре тога била је окончана четворогодишња градња нове католичке цркве у Великом Бечкереку (1864-1868), ${ }^{67}$ о којој је Wochenblatt такође редовно извештавао. ${ }^{68}$ Иако до тада можда и није био на челу црквене општине, Швикер је морао бити упућен у дешавања око градње, будући да је његов покровитељ и пријатељ Александар Бонац био иницијатор тог подухвата. Швикер се на новом положају ангажовао на прикупљању прилога за унутрашње уређење цркве, односно набавци бочних олтара и клупа за исповести верника (Beichtstühle), ${ }^{69}$ као и на унајмљивању оргуљаша. ${ }^{70}$ Почетком новембра 1869. у Wochenblatt-у је освануо кратак текст којим се опростио од Великобечкеречана:

\footnotetext{
${ }^{64} \mathrm{O}$ томе в.: Отварање завода за чување мале деце, GWb 12, 23.3.1872, 8; GWb 13, 30.3.1872, 8; GWb 14, 6.4.1872, 6 .

${ }^{65}$ Anzeige, GWb 21, 22.5.1869, 1; GWb 22, 29.5.1869, 5.

${ }^{66}$ Rede bei Eröffnung der General-Versammlung der r. kath. Kirchengemeinde in Gr. Becskerek am 30. Mai 1869, gehalten vom Kirchen-Präses, Prof. Joh. Heinr. Schwicker, GWb 23, 5.6.1869, 9.

${ }^{67}$ Нова црква, подигнута у неороманском стилу, посвећена је св. Јану Непомуку; извођач радова био је локални грађевински предузимач Стеван Ђорђевић, а унутрашњост су осликали сликари Јозеф Гојгнер из Бечкерека и Берталан Секељ из Будимпеште. Иницијатор и један од главних покретача овог посла био је већ поменути Александар Бонац, Швикеров пријатељ и покровитељ. О цркви в.: Die neue r. k. Pfarrkirche in Gr. Becskerek und ihre Geschichte (mit einer Abbildung), GWb 28, 14.7.1866, 7-10; F. Milleker, Geschichte der Stadt Veliki Bečkerek 1333-1918, Wrschatz 1933, 59-60; А. Станојловић, Петровград, Зрењанин 2004², 134; Vesna Karavida, Zrenjanin - graditeljska baština, Zrenjanin 2002.

${ }^{68}$ Die feierliche Grundsteinlegung zur r. k. Pfarrkirche in Gr. Becskerek, GWb 39, 24.9.1864, 8-9; Die neue r. $k$. Pfarrkirche in Gr. Becskerek und ihre Geschichte (mit einer Abbildung), GWb 28, 14.7.1866, 7-10; An die Katholiken von Groß-Becskerek!, GWb 43, 24.10.1868, 12; Die neue Orgel in der r. kath. Pfarrkirche, GWb 44, 31.10.1868, 12; Kundmachung und Einladung, GWb 48, 14.11.1868, 1; Die Einweihung der r. kath. Kirche in Gr. Becskerek, am Dienstag den 24. November 1868, GWb 48, 28.11.1868, 11. Није искључено да је Швикер био аутор неких од ових текстова, иако су они остали непотписани (Ф. К.).

${ }^{69}$ Kundmachung, GWb 39, 25.9.1869, 7; GWb 41, 9.10.1869, 1.

${ }^{70}$ Kundmachung, GWb 41, 9.10.1869, 1.
} 
Свим пријатељима и познаницима, а нарочито поштованим родитељима мојих некадашњих ученика, при свом одласку изричем срдачно све најбоље у животу и препоручујем се њиховој пријатељској успомени.

Јох. Хајнр. Швикер Директор и професор Краљевског угарског Централног наставног завода у Будиму ${ }^{71}$

Извори и литература:

Gross-Becskereker Wochenblatt (1857-1869).

Грубић, Рајка, Занатлије и трговии у прошлости Зрењанина (од XVI до прве половине XX века), Рад музеја Војводине 49, Нови Сад 2007.

Karavida, Vesna, Zrenjanin - graditeljska baština, Zrenjanin 2002.

Krischan, Alexander, Deutsche Beiträge zur Banater Historiographie. Biobibliographische Skizzen, Freiburg 1983.

Milleker, Felix, Geschichte der Stadt Veliki Bečkerek 1333-1918, Wrschatz 1933.

Nemet, Ferenc, Istorija štampe u Velikom Bečkereku 1849-1918, Zrenjanin 2007.

Petri, Anton Peter, Biographisches Lexikon des Banater Deutschtums, Marquartstein 1992.

Привилегија Марије Терезије којом уздиже општину Велики Бечкерек на степен тржишта 1769. године у Бечу, Архивска грађа градске Државне архиве у Зрењанину, год. I, св. 1, Зрењанин 1953.

Станојловић, Александар, Петровград, Зрењанин $2004^{3}$.

Томандл, Миховил, Преписка између J. Х. Швикера и епископа Теофана Живковића, ГИД VIII, Нови Сад 1935, 422-438; ГИД ІХ, Нови Сад 1936, 65-78.

Schwicker, Johann Heinrich, Politische Geschichte der Serben im Ungarn. Nach archivalischen Quellen dargestellt, Budapest 1880.

Швикер, Јохан Хајнрих, Политичка историја Срба у Угарској (превод: Томислав Бекић, приређивач Славко Гавриловић), Нови Сад 1995.

Швикер, Јохан Хајнрих, Хисторија унијаћења Срба у Жумберку, Крагујевац 1991.

\footnotetext{
${ }^{71}$ Abschied, GWb 45, 6.11.1869, 3.
} 


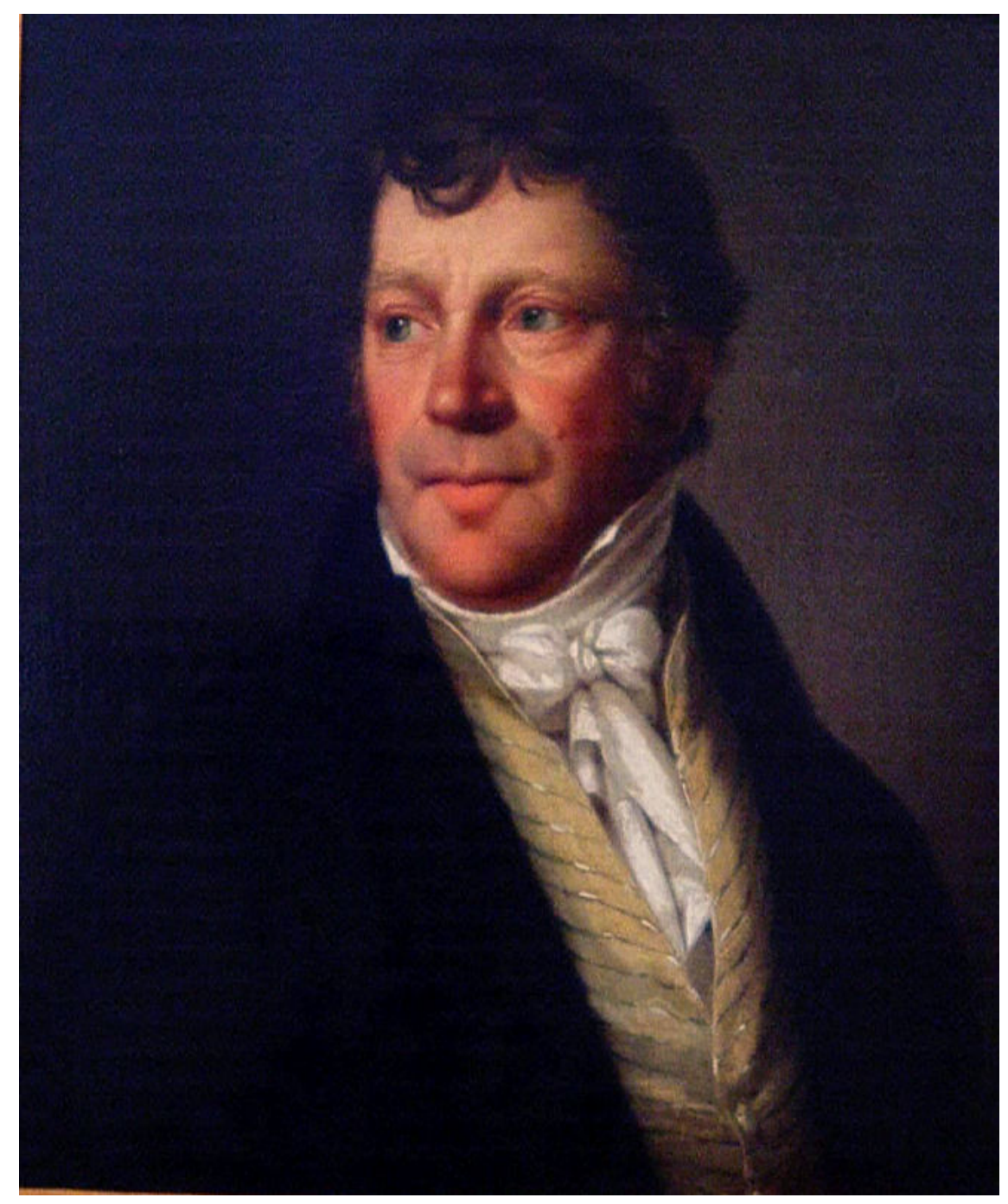

Константин Данил, Портрет историчара Швикера

(Народни музеј Зрењанин) 


\title{
JOHANN HEINRICH SCHWICKER AND HIS SOCIAL ACTIVISM IN VELIKI BEČKEREK
}

\begin{abstract}
Summary
Renowned scholar, pedagog and historian Johann Heinrich Schwicker is a widely recognized figure in Serbian historiography, mostly due to his work Political History of Serbs in Southern Hungary. From 1857 till 1869 he resided in Veliki Bečkerek, where his participation in the city's social life can be traced thanks to the local weekly newspaper Gross-Becskereker Wochenblatt. While working as a teacher in the local Grammar School, Schwicker also acted as a secretary of Veliki Bečkerek's Chamber of Merchants, member of Veliki Bečkerek Steamship company and Chairman of the Catholic Church Congregation. Here he published his first major historical work - History of Banat of Tamiš, initiated the establishment of a secondary modern school and launched the pedagogical review. In 1869 Schwicker moved to Buda, where he occupied numerous educational positions, until his death in 1902.
\end{abstract}

Keywords: Johann Heinrich Schwicker, Gross-Becskerek, Banat, Torontál County, historiography, pedagogy, Gross-Becskereker Wochenblatt.

FILIP KRČMAR

\section{JOHANN HEINRICH SCHWICKER UND SEINE GESELLSCHAFTLICHE TÄTIGKEIT IN GROSS-BECSKEREK}

\section{Zusammenfassung}

Wegen seiner Politische Geschichte der Serben im Südungarn stellt der angesehene Wissenschaftler, Pädagog und Historiker Johann Heinrich Schwicker eine bekannte Name innerhalb serbischer Geschichtsschreibung dar. Von 1857 bis 1869 wohnte Schwicker in Gross-Becskerek, wo seine gesellschaftliche Aktivität auf Grund des lokalen Gross-Becskereker Wochenblatt gut dokumentiert ist. Als Lehrer in hiesige Gymnasium tätig, Schwicker war Sekretär der Gross-Becskereker Kaufmanns-Halle, Mitglied der Gross-Becskereker Dampfschifffahrts-Gesellschaft und Vorsteher der r.-kath. Kirchengemeinde. Hier veröffentlichte Schwicker seine Geschichte des Temeser Banats, initiierte die Errichtung einer Realschule im Gross Becskerek und begründete die pädagogische Zeitschrift Ungarische Schulbote. Im 1869 übersiedelte sich Schwicker nach Ofen.

Schlüsselwörter: Johann Heinrich Schwicker, Gross-Becskerek, Banat, Torontaler Komitat, Geschichtsschreibung, Pädagogie, Gross-Becskereker Wochenblatt. 